\title{
Occurrence of Porcellanopagurus nihonkaiensis (Decapoda: Anomura: Paguroidea: Paguridae) in Korean Waters
}

\author{
Hyun Sook Ko ${ }^{1 *}$ and Patsy A. McLaughlin ${ }^{2}$ \\ 'Department of Biological Sciences, Silla University, Busan 617-736, Korea \\ ${ }^{2}$ Shannon Point Marine Center, Western Washington University, 1900 Shannon Point Road, \\ Anacortes, WA 98221-9081B, U.S.A.
}

\begin{abstract}
A pagurid crab carrying half of a bivalve shell was collected from Jejudo Island and identified as Porcellanopagurus nihonkaiensis. A diagnosis with illustrations of this specimen is presented. Although, Komai and Takeda (2006) reported this species as rare and known only from Japan, its range is now extended to Korean waters. At present, it is the only species of the genus Porcellanopagurus represented in Korean waters.
\end{abstract}

Key words: Anomura, Paguridae, Porcellanopagurus nihonkaiensis, Korea

\section{INTRODUCTION}

The very interesting hermit crab Porcellanopagurus nihonkaiensis Takeda, 1985, was described on the basis of a single female from Iida Bay, east of the Noto Peninsula, in the East Sea (Sea of Japan). McLaughlin (2000b) incorrectly cited the type locality as the Ogasawara Islands, which instead was the type locality for $P$. truncatifrons Takeda, 1981. Porcellanopagurus nihonkaiensis was reported briefly from Izu-ohshima Island by Okuno and Arima (2004) and more recently by Komai and Takeda (2006) from the Sagami Sea and Boso Peninsula. These latter authors remarked that it was a rare species known only from Japan. Thus its collection by the first author in Korean waters generated surprise and considerable interest. This discovery represents a major range extension for the species. It was collected under a large stone at Jejudo Island (Mosulpo) by SCUBA diving and found with its telson and endopods of the uropods securely lodged in the umbo of the bivalve.

Takeda's (1985) description was brief, with only the shield, ocular peduncles, sixth pleonal somite and uropods illustrated. Komai and Takeda (2006) presented a complete and well illustrated redescription, thus the present authors had no difficulty in identifying the Korean specimen. Nonetheless, we have verified our identification through a comparison of our specimen with a pair of specimens from Tateyama Bay off Banda, Boso Peninsula, courtesy of Dr.

\footnotetext{
*To whom correspondence should be addressed

Tel: 82-51-999-5473, Fax: 82-51-999-5176

E-mail: hsko@silla.ac.kr
}

Komai, Natural History Museum and Institute, Chiba, Japan. In view of the detailed presentation of Komai and Takeda (2006), a second redescription of this species is unwarranted. However, we include a diagnosis and illustrations of the Korean specimen for the benefit of regional interests.

One measurement, shield length (sl), measured from the midpoint of the rostrum to the midpoint of the posterior margin of the shield provides an indication of animal size. Terminology follows that of McLaughlin (2000b) except for the substitution of pleon for abdomen as defined by Schram and Koenemann (2004). The specimens on loan from the Natural History Museum and Institute, Chiba (CBM-ZC), are being returned to that institution. The Korean specimen is deposited in the first author's collection at Silla University, Busan, Korea.

\section{SYSTEMATIC ACCOUNTS}

Superfamily Paguroidea Latreille, 1802

Family Paguridae Latreille, 1802

Genus Porcellanopagurus Filhol, 1885

${ }^{1} *$ Porcellanopagurus nihonkaiensis Takeda, 1985

(Figs. 1A-F, 2)

Porcellanopagurus japonicus: Miyake, 1978, p. 118 (in part).

Porcellanopagurus nihonkaiensis Takeda, 1985, p. 141, fig. 1B, 2; McLaughlin, 2000b, p. 394, key; Okuno and Arima, 2004, p. 64, fig. 4C; Komai and Takeda, 2006, p. 125, figs. $10-12$. 
Material examined. Korea. 1 male ( $\mathrm{sl}=3.3 \mathrm{~mm}$ ), Mosulpo $\left(33^{\circ} 12^{\prime} \mathrm{N}, 126^{\circ} 15^{\prime} \mathrm{E}\right.$ ), Jejudo Island, 9 June 2006 (H.S. Ko: SUZCR 10211), by Scuba diving at $15 \mathrm{~m}$ in depth.

Japan. 1 male $(\mathrm{sl}=3.2 \mathrm{~mm}), 1$ ovigerous female $(\mathrm{sl}=2.7$ $\mathrm{mm}$ ), Tateyama Bay off Banda, Bozo Peninsula 30-60 m, 24 May 1990 (M. Osawa: CBM-ZC 7869).

Description (based on Korean specimen). Shield (Fig. 1A) broader than long; cervical groove only weakly delimited laterally. Rostrum broad, almost subquadrate, but with prominent, rounded median protuberance. Lateral projections broadly triangular, terminally subacute or acute. First anterior carapace lobe triangular, terminally acute or subacute considerably distant from lateral projections; second carapace lobe broadly rounded; posterior carapace lobe moderately slender, terminally subacute, extending laterally well beyond margins of second anterior lobes. Ocular peduncles short, stout, 0.4 of shield; corneas 0.5 of peduncle; ocular acicles small, not visible dorsally. Antennular and antennal peduncles overreaching distal corneal margins; antennular peduncles longest; antennal acicle terminally subacute, unarmed; antennal flagellum long, considerably overreaching right cheliped.

Chelipeds markedly dissimilar. Right cheliped (Fig. 1B) massive; dactyl articulating somewhat obliquely, dorsal surface convex, with scattered quite short setae, ventral surface with numerous long setae; palm somewhat swollen
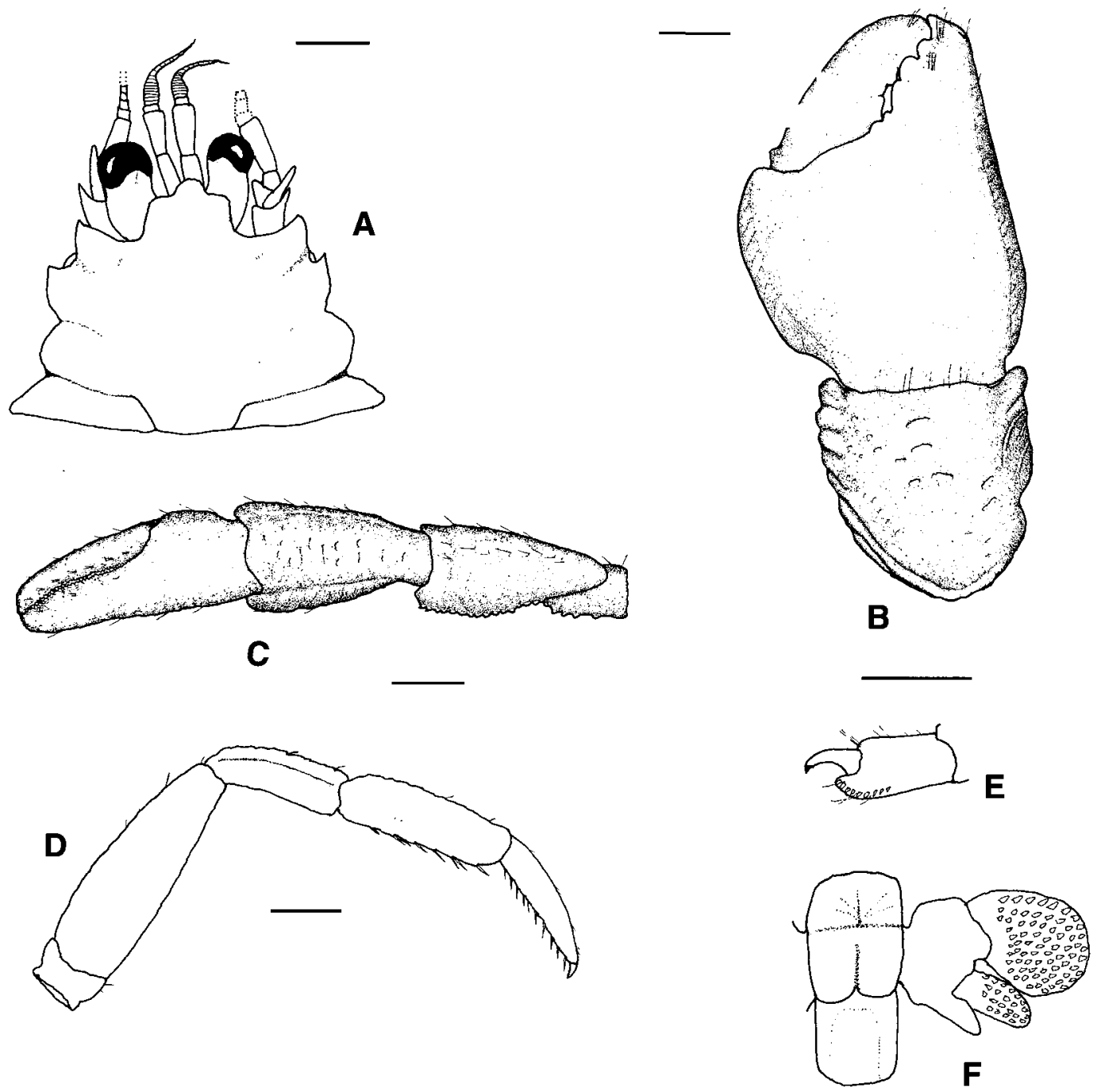

Fig. 1. Porcellanopagurus nihonkaiensis, male $(\mathrm{s} /=3.3 \mathrm{~mm}$ ). A, shield and cephalic appendages (aesthetascs omitted); $\mathrm{B}$, chela and carpus of right cheliped (most setae omitted); C, left cheliped; D, right second pereopod (lateral view); $E$, dactyl and propodus of left fourth pereopod (lateral view); $F$, sixth pleomere and left uropod (dorsal view), telson indicated ventrally. Scale bars $=1 \mathrm{~mm}$ (AF). 


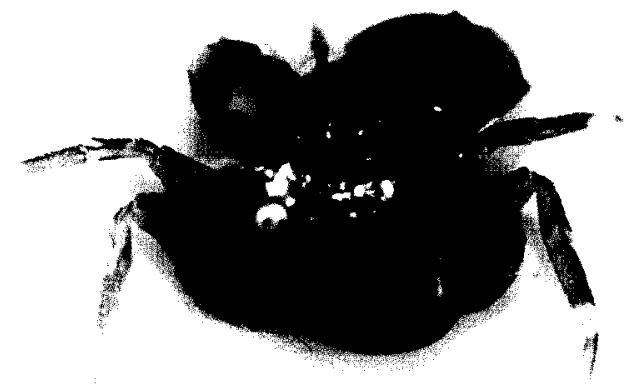

Fig. 2. Porcellanopagurus nihonkaiensis, male, dorsal view of live specimen.

dorsoventrally, with convex dorsal surface very faintly pitted and with scattered very short setae, dorsomesial margin distinct, dorsolateral margin faintly delineated, lateral face microscopically crenate, ventral surface weakly granular and with tufts of long setae; carpus with dorsomesial margin cut distally by oblique low ridges, carinate proximally, dorsal surface with scattered short ridges and few tubercles mesially, dorsolateral margin not delimited, lateral face with several low, sinuous, oblique ridges, ventral surface with tufts of long setae; merus with few small spines on ventral margins. Left cheliped (Fig. 1C) moderately slender; dactyl unarmed; palm with dorsomesial and dorsolateral margins weakly delimited, ventral surface with tufts of long setae; carpus elevated in midline, surface with numerous low somewhat rugged protuberances; dorsomesial and dorsolateral margins distinctly delimited, each rounded and with short oblique low ridges, ventral surface with tufts of long setae; merus with row of small spines on ventromesial margin. Ambulatory legs (Fig. 1D) similar to each other; dactyls slightly shorter to approximately equal to lengths of propodi, ventral margins each with 10 or 11 corneous spines; propodi with low protuberances and few short setae on each dorsal surface, ventral surfaces each with row of corneous spines, fewer in number on third pereopods; carpi with row of protuberances and few short setae on dorsal surfaces but no distinct dorsodistal spines, lateral faces each with longitudinal ridge; meri each with low protuberances and few short setae on dorsal surfaces, ventrolateral margins each with row of tiny tubercles or spinulose protuberances. Fourth pereopods (Fig. 1E) semichelate; dactyl slightly hooked; propodal rasp consisting of single row of corneous scales. Fifth pereopods minutely chelate; male gonopores each with circumscribed by tuft of setae, no papilla or short sexual tube.

Pleon markedly reduced; male pleopods absent. Sixth pleomere (Fig. 1F) with transverse suture, posterior portion divided by prominent longitudinal groove; uropods symmetrical, exopods more than twice diameter of endopods, each with large rasp of corneous scales. Telson (Fig. 1F) membranous, separated from sixth pleomere by large, equally membranous region, and carried ventrally; anus terminal.

Coloration of Japanese specimens. Carapace, chelipeds and ambulatory legs generally tan to orange-brown. Ocular peduncles each with brownish band distally. Chelipeds each with dactyl and fixed finger lighter. Propodi of ambulatory legs each white distally [from photo of Okuno and Arima, (2004: 4C)].

Coloration of Korean specimen. Quite similar to Japanese specimens. Penultimate segment of antennular peduncle pale blue ventrally, with dark brownish band distally.

Habitat. Hard substrates, with halves of bivalve shells as carcinoecia.

Distribution. Japan from Kamogawa, Boso Peninsula to Shionomiski, Kii Peninsula, Iida Bay, East Sea (Sea of Japan), Korea; 15-20 m.

Remarks. Although minor differences are seen between the Korean specimen and the Japanese specimen from Sagami Bay illustrated by Komai and Takeda (2006), these fall well within the range of variability expected in species of Porcellanopagurus. When compared with the Japanese male and ovigerous female from the Boso Peninsula, the rostrum of our Korean specimen is broader, more subquadrate, with the median projection larger and more rounded. The first anterior carapace lobes are terminally acute or subacute in our specimen, but acute or with a terminal spinule in the Japanese specimens. The size and acuteness of the armature of the ambulatory legs and the prominence of the ridges of the chelipeds are greater in the Japanese specimens. The shield lengths differ little between the Korean and Japanese males examined; however, the carapace of our specimen is appreciably broader [ $3.6 \mathrm{~mm}$ vs. $3.3 \mathrm{~mm}$ measured at the level of second carapace lobes], indicating that growth is reflected more in shield width than in length. As is common in numerous pagurid genera, spination appears to be reduced in prominence with increasing body size, at least in males of $P$. nihonkaiensis.

Although Takeda (1981) reported the telson absent in $P$. truncatifrons, McLaughlin (2000b) suggested that the telson might simply have been folded under the pleon as has proved to be the case in $P$. nihonkaiensis. These two species, together with $P$. haptodactylus McLaughlin, 2000b and $P$. adelocercus McLaughlin and Hogarth, 1998, would then form a clade within the genus characterized by posterior displacement of the telson. In her key to the species of Por- 
cellanopagurus, McLaughlin (2000b) included P. nihonkaiensis among the species with triangular or subtriangular rostra and Komai and Takeda (2006) characterized this species as having a trilobed rostrum. The rostrum of our Korean specimen might be considered trilobed, but it could never be judged triangular, or even subtriangular. Perhaps it would be more appropriate to consider the rostrum of $P$. nihonkaiensis as truncate, but with a median protuberance. All four species presumably sharing the distinctive ventral carriage of the telson would then also share the truncated rostra. Porcellanopagurus adelocercus and $P$. haptodactylus may be distinguished from $P$. nihonkaiensis and $P$. truncatifrons by their truly trilobed rostra, and from each other by the armature of the right chela and the spines on the ventral margins of the ambulatory dactyls. In $P$. adelocercus the dorsal surface of the dactyl and the distomesial surface of the palm are tuberculate; the ventral margins of the dactyls of the ambulatory legs each has a row of 5-7 corneous spines. In contrast, the dorsal surfaces of the dactyl and palm are unarmed or minutely granular or spinulose in $P$. haptodactylus; the dactyl of each ambulatory leg has a row of 9-11 spines on the ventral margin. Characters that distinguish $P$. nihonkaiensis from $P$. truncatifrons include the median protuberance of the rostrum, the acute or subacute, well developed first anterior carapace lobes that are well removed from the lateral projections, the broader and elongate posterior carapace lobes that extend beyond the margins of the second anterior carapace lobes, and the number of spines on the ventral margins of the ambulatory dactyls, 9-12 in P. nihonkaiensis, but 7 in $P$. truncatifrons.

\section{DISCUSSION}

In early zoeal development of the majority of paguroids, the telson is fused with the sixth pleomere, but becomes free toward the end of the zoeal phase. In megalopal, juvenile and adult stages, the telson remains free, but contiguous with the sixth pleomere. However, in two species of Porcellanopagurus Filhol, 1885, the unique condition of the adult telson being separated from the sixth pleomere by membranous tissue and carried ventrally beneath the pleon was reported by McLaughlin and Hogarth (1998) and McLaughlin (2000b). McLaughlin (2000b) reported a similar condition in one species of the closely related genus Solitariopagurus Türkay, 1986, and noted that species in both genera also shared the unusual character of a terminal anus. Okuno and Arima (2004) and Komai and Takeda (2006) reported a similar telsonal separation and terminal anus for $P$. nihonkaiensis. We have confirmed these phenomena in our Korean specimen as well.
In a review of the old debate by Bowman (1971) and Schminke (1976) regarding the position of the anus in crustaceans, Knopf et al. (2006) examined a considerable number of pan- and pericaridan species and found the position of the anus variable. There did not appear to be an obligatory relationship between anal position and telsonal development, or lack thereof. Although not explicitly suggested, some of their observed variability seemed to correlate with unusual habitats or habitat requirements. The terminal position of the anus in Porcellanopagurus and Solitariopagurus species may similarly be a response to habitat. Apparently the preferred carcinoecia of these taxa are halves of bivalve mollusk shells, atypical habitats for hermit crabs. Roberts (1972) found the position of the anus in zoeal stages of $P$. edwardsi Filhol, 1885, to be ventral; however, McLaughlin (2000a) documented a posterior shift in the anus from megalopa to first crab stage, with an accompanying shortening of the pleon through lateral expansion of the pleonal tissue. With increased size, pleonal growth appeared somewhat volumetric. McLaughlin (2000b) speculated that such growth could explain the ostensible migration of the female pleopods to a dorsal position and perhaps the posterior shift of the anus.

Although no studies of "shell carrying", comparable to those for gastropod inhabiting hermit crabs, have been done, McLaughlin (2000b) reported that specimens of Porcellanopagurus filhol de Saint Laurent and McLaughlin, 2000 , in New Zealand were found with their telsons and the endopods of their uropods securely lodged in the umbos of their bivalve shells. However, McLaughlin and Lemaitre (2007) reported that specimens of this same species from Sagami Bay, Japan, occupied numerous bivalve shells that lacked well developed umbos. These authors suggested that the carcinoecia might be held in place by the combined use of the telsons, spatulate rami of the uropods and the posterior fleshy portions of the pleons.

Porcellanopagurus filholi is a species in which the telson and sixth pleomere are contiguous; the telson is terminal. But what about those species in which the telson and sixth pleomere are separated by membranous tissue? McLaughlin (2000b) indicated that for $P$. adelocercus and for $P$. haptodactylus there was no clear indication that the tergite of the sixth pleomere was the most posterior part of the somite, as it was in most paguroids. It appeared as if there might be additional posterior growth of the somite, which could account for the displacement of the telson. This type of pleomere growth also occurs in $P$. nihonkaiensis. Komai and Takeda (2006) did not identify the bivalves utilized by their specimens; however, Okuno and Arima (2004) reported that their single male had been lodged in a shell of Hawaiarca uwaensis (Yokoyama). Our Korean representa- 
tive also occupied a valve of a species of the family Arcidae, with a reasonably well developed umbo. However, the membranous integument of the telson in $P$. nihonkaiensis makes it unlikely that this structure could contribute to "shell carrying". Consequently the normally terminal position of the telson might be disadvantageous. It is most probable that shells are held in place over the dorsal surfaces of the pleons through the use of the rasps of the uropods in combination with hydrostatic pressure in the pleons, possibly aided by the somewhat hooked dactyls of the fourth pereopods; the disassociated telsons are conveniently folded under the pleons.

\section{ACKNOWLEDGEMENTS}

The authors are indebted to Dr. Tomoyuki Komai for the loan of the Japanese representatives of $P$. nihonkaiensis. This is, in part, a scientific contribution from the Shannon Point Marine Center, Western Washington University.

\section{REFERENCES}

Bowman, T.E., 1971. The case of the nonubiquitous telson and the fraudulent furca. Crustaceana, 21: 165-175.

Filhol, H., 1885. Description of d'un nouveau genre de Crustacé provenant de la Nouvelle-Zélande. Bull. Soc. Philom. Paris, 9: 47-48.

Knopf, F., S. Koenemann, F.R. Schram and C. Wolff, 2006. The urosome of the Pan- and Pericarida. Contr. Zool., 75: $1-21$.

Komai, T. and M. Takeda, 2006. A review of the pagurid hermit crab (Decapoda: Anomura: Paguroidea) fauna of the Sagami Sea, central Japan. Mem. Natn. Sci. Mus. Tokyo, 41: 71-144.

Latreille, P.A., 1802. Histoire naturelle, générale et particulère, des Crustacés et des Insectes. F. Dufart, Paris, 3: 1-480.

McLaughlin, P.A., 2000a. Megalopal and early crab stages of
Porcellanopagurus edwardsi Filhol Decapoda: Anomura: Paguridea). Proc. Biol. Soc.Wash., 113: 721-730.

McLaughlin, P.A., 2000b. Crustacea: Decapoda: Species of Porcellanopagurus Filhol and Solitariopagurus Türkay (Paguridae), from the New Caledonia area, Vanautu, and the Marquesas: new records, new species. In Crosnier, A. (ed.), Résultats des Campagnes MUSORSTOM, 21. Mém. Mus. Natn. Hist. nat., 184: 389-414.

McLaughlin, P.A. and P.J. Hogarth, 1998. Hermit crabs (Decapoda: Anomura: Paguridea) from the Seychelles. Zool. Verhandel., 318: 1-48.

McLaughlin, P.A. and R. Lemaitre, 2007. A new and distinctive species of the hermit crab genus Catapaguropsis (Crustacea: Decapoda: Anomura: Paguroidea: Paguridae) from the South China Sea. Zootaxa, 1560: 31-41.

Miyake, S., 1978. The crustacean Anomura of Sagami Bay, Biol. Lab. Imperial Household, Tokyo, pp. 1-200 (English), 1-161 (Japanese).

Okuno, J. and H. Arima, 2004. An annotated checklist of inshore hermit crabs (Crustacea, Decapoda, Anomura of Izuohshima Island, the northern Izu Islands, Japan. Bull. Biogeogr. Soc. Jap., 59: 49-69.

Roberts, P.E., 1972. Larvae of Porcellanopagurus edwardsi Filhol, 1885 (Crustacea: Decapoda: Paguridae) from Perseverance Harbour, Campbell Island. Jour. Royal Soc. New Zealand, 2: 383-391.

Schminke, H.K., 1976. The ubiquitous telson and the deceptive furca. Crustaceana, 30: 292-300.

Schram, F.R. and S. Koenemann, 2004. Developmental genetics and arthropod evolution on body regions of Crustacea. In Scholtz, G. Evolutionary Developmental Biology of Crustacea. Crustacean Issues, A.A. Balkema Publishers, Lisse, 15: 75-92.

Takeda, M., 1981. A new hermit crab of the genus Porcellanopagurus from the Ogasawara Islands. Bull. Biogeogr. Soc. Jap., 36: 8-13.

Takeda, M., 1985. Occurrence of a new hermit crab of the genus Porcellanopagurus in the Sea of Japan. Mem. Natn. Sci. Mus. Tokyo, 18: 141-144.

Received December 18, 2007 Accepted March 6, 2008 